\title{
STUDI EFEKTIVITAS PADA MESIN PENCACAH DAUN TEH OPEN TOP ROLLER MENGGUNAKAN METODE OVERALL EQUIPMENT EFFECTIVENESS
}

\author{
Muhammad Zulfikri ${ }^{*}$, Alfian H. Siregar ${ }^{2}$, Zulkifli Lubis ${ }^{3}$, Ahmad H. Siregar ${ }^{4}$ \\ 1,2,3,4 Departemen Teknik Mesin, Fakultas Teknik, Universitas Sumatera Utara \\ Email: zullfikri@gmail.com
}

\begin{abstract}
ABSTRAK
Mesin Open Top Roller (OTR) adalah suatu mesin penggulung daun teh yang terdapat pada pabrik PT Perkebunan Nusantara IV Unit Bah Butong yang berfungsi untuk mengeluarkan cairan sel pucuk layu dengan menggulung teh pucuk layu. Untuk mengetahui tingkat keefektifan dari mesin penggulung Open Top Roller (OTR) maka dilakukan analisa dengan metode OEE (Overall Equipment Effectiveness), Six Big Losses, dan menganalisa tingkat resiko kegagalan pada komponen mesin penggulung Open Top Roller (OTR) digunakan metode FMEA (Failure Mode and Effect Analysis) sehingga didapatkan nilai Risk Priority Number (RPN) yang tertinggi sebagai penyebab dominan kegagalan yaitu komponen Silinder penggulung, meja penggiling, Poros engkol, Elektro motor dan V-belt. Berdasarkan analisa didapat hasil perhitungan dengan nilai rata-rata availability $89.74 \%$, performa efficiency $75.79 \%$, rate of quality product $100 \%$ dan OEE (Overall Equipment Effectiveness) yaitu $67.99 \%$ dan nilai Risk Priority Number (RPN) pada komponen-komponen Silinder penggulung 21, meja penggiling 105, Poros engkol 120, Elektro motor 63 dan V-belt 30. Dengan adanya analisa ini dapat dirancang pencegahan sehingga dapat mengurangi terjadinya breakdown pada mesin penggulung Open Top Roller (OTR).
\end{abstract}

Kata kunci: OTR (Open Top Roller), OEE (Overall Equipment Effectiveness), Six Big Losses, dan FMEA (Failure Mode and Effect Analysis)

\begin{abstract}
Open Top Roller machine (OTR) is a machine for rolling tea leaves found on the factory of PT Perkebunan Nusantara IV Unit Bah Butong that serves to discharge the cell shoots wither with rolling tea shoots withering. To find out the level of effectiveness of rolling machine Open Top Roller (OTR) then conducted the analysis with the method of OEE (Overall Equipment Effectiveness), the Six Big Losses, and analyse the level of risk of failure on the component of rolling machine Open Top Roller (OTR) used a method of FMEA (Failure Mode and Effect Analysis) so that the obtained value of the Risk Priority Number (RPN) the highest as the dominant cause of failure for components namely rolling cylindrical, table grinders, crankshaft, electro motor and V-belt. Based on the analysis of the obtained results of the calculation of the average value of $89.74 \%$ availability, performance efficiency $75.87 \%$, rate of quality product $100 \%$ and OEE (Overall Equipment Effectiveness) $67.99 \%$ and the value of the Risk Priority Number (RPN) in components for rolling cylindrical 21, table grinder 105, crankshaft 120, electro motor 63 and V-belt 30. The existence of this analysis can be designed so that prevention can reduce the occurrence of breakdown on the rolling machine Open Top Roller (OTR).
\end{abstract}

Keyword: OTR (Open Top Roller), OEE (Overall Equipment Effectiveness), Six Big Losses, dan FMEA (Failure Mode and Effect Analysis)

\section{PENDAHULUAN}

Perawatan terhadap mesin - mesin dalam dunia industri/manufaktur merupakan aspek penting yang tidak bisa diabaikan. Karena setiap mesin pasti membutuhkan perawatan yang tepat demi berlangsungnya proses produksi secara berkelanjutan. Maka dengan itu dibutuhkan manajemen yang baik serta metode - metode yang tepat dalam perawatan mesin tersebut sehingga umur mesin pun bisa lebih lama dan dapat menekan biaya pengeluaran. Mesin dapat dikatakan berupa aspek penting di dalam dunia perindustrian untuk menghasilkan suatu produk di dalam suatu perusahaan, sehingga ketika mesin mengalami masalah kerusakan, maka hal hal tersebut dapat mengakibatkan berhentinya proses produksi, keefisiensi mesin menurun, 
melonjaknya biaya perawatan, turunnya kualitas dari porduk - produk yang dihasilkan dan juga dapat mengganggu kinerja karyawan.

Dalam penerapan Total Productive Maintenance ini akan memberikan metrik kuantitatif yang disebut Overall Equipment Effectiveness (OEE) untuk mengukur produktivitas mesin dan meningkatkan efektifitas peralatan ini produksi sehingga tercapai volume lebih besar dengan hasil yang baik sehingga biaya produksi yang dikeluarkan lebih rendah. Dengan mengaplikasikan prinsip Total Productive Maintenance dapat meminimalisir kerusakan pada mesin dan masalah umum yang sering terjadi pada mesin.

PT Perkebunan Nusantara IV (PTPN IV) merupakan perusahaan yang bergerak dibidang Usaha agroindustri. PT Perkebunan Nusantara IV Unit Bah Butong mengelolah teh hitam dengan kapasitas 100 ton perhari. Dalam proses produksinya, perusahaan PT Perkebunan Nusantara IV menggunakan sistem pengolahan orthodox. Sistem Pengolahan orthodox adalah sistem pengolahan teh dengan tingkat layu yang berat dan sifat penggulungan yang lebih ringan.

PT Perkebunan Nusantara IV unit Bah Butong mengunakan .mesin-mesin dan peralatan-peralatan yang mendukung proses produksinya dalam Menghasilkan teh hitam. Disini saya memilih mesin penggulung OTR (Open Top Roller) dikarenakan apabila mesin ini tidak beroperasi maka proses produksi akan terhenti.

mesin penggulung ini yang berfungsi mengeluarkan cairan sel pucuk layu dan menggiling teh pucuk layu. Mesin ini berbentuk silinder berputar dengan kecepatan $44 \mathrm{rpm}$. Open Top Roller berdiameter 1,2 meter dan Panjang 2,7 meter.

Penelitian ini dilakukan untuk menganalisa keeffektivitasan mesin Open Top Roller yang terdapat pada perusahaan PT Perkebunan Nusantara IV (PTPN IV) Unit Bah Butong dengan melakukan penerapan Total Productive Maintenance untuk melihat faktor mana dari six big losses tersebut yang dominan untuk mempengaruhi terjadinya penurunan efektivitas mesin Open Top Roller. Untuk memecahkan permasalahan yang ditemukan menggunakan metode Overall Equipment Effectiveness (OEE) dan Failure Mode and Effect Analysis (FMEA). Metode FMEA adalah metode yang digunakan untuk mengidentifikasi bentuk kegagalan yang menyebabkan sistem kegagalan fungsi dan untuk memastikan pengaruh kegagalan berhubungan dengan setiap bentuk kegagalan lainnya. Dengan demikian penulisan ini akan memberikan usulan perbaikan efektivitas mesin Open Top Roller dalam usaha meningkatkan efisiensi produksi pada perusahaan melalui penerapan Total Productive Maintenance.

\section{METODE}

Penelitian di laksanakan di PT. Perkebunan Nusantara IV Unit Bah Butong, Kab. Simalungun, Sumatera Utara. Objek yang akan di teliti yaitu mesin Open Top Roller dapat dilihat pada gambar 1 yang berfungsi untuk mengeluarkan cairan sel pucuk layu dan menggulung teh pucuk layu. 


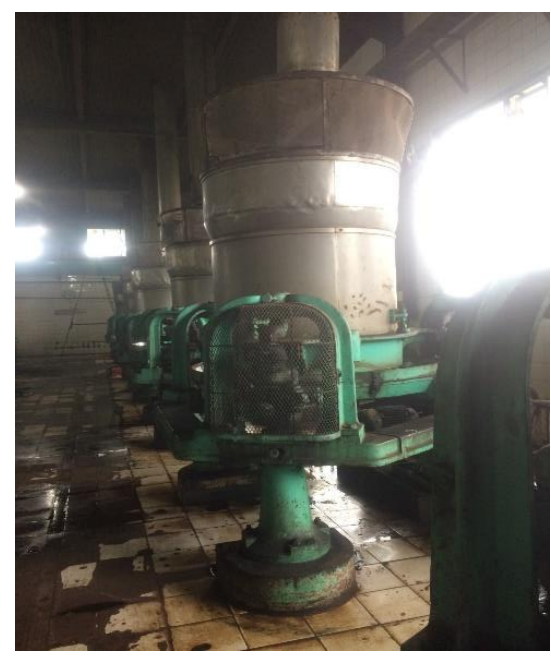

Gambar 1. Open Top Roller

Mesin Open Top Roller menggunakan elektro motor sebagai penggerak. Daya putaran yang dihasilkan pada elektro motor akan didistribusikan menggunakan v-belt ke gearbox. Gearbox bertujuan untuk menstransmisikan putaran pada mesin Open Top Roller dan merubah arah putaran. Gearbox dihubungkan ke poros engkol untuk menggerakkan silinder penggulung dan meja penggiling. Berikut spesifikasi mesin Open Top Roller dan elektro motor dapat dilihat pada tabel 1 .

Tabel 1. Spesifikasi mesin Open Top Roller

\begin{tabular}{|ll|ll|}
\hline \multicolumn{3}{|c|}{ SPESIFIKASI } \\
\hline \multicolumn{3}{|c|}{ Mesin DIBN } & \multicolumn{2}{c|}{ Sistem penggerak } \\
\hline Merk & $:$ TEHA & Merk $:$ TECO \\
\hline Panjang $\quad: 2700 \mathrm{~mm}$ & Daya $: 30 \mathrm{Hp}$ \\
\hline Bentuk Model $\quad:$ Horizontal & Frekuensi $: 50 \mathrm{~Hz}$ \\
\hline Diameter Silinder $: 1200 \mathrm{~mm}$ & Putaran $: 1450 \mathrm{Rpm}$ \\
\hline Kapasitas $: 375 \mathrm{~kg}$ & \\
\hline Daya & $: 20 \mathrm{Hp}$ & \\
\hline Putaran & $: 44 \mathrm{Rpm}$ & \\
\end{tabular}

Setelah mengumpulkan data historis, dilakukan untuk mengetahui nilai keefektivitasan suatu mesin adalah dengan melakukan perhitungan-perhitungan sebagai berikut :

1. Menghitung nilai Overall Equipment Effectiveness ( OEE )

Overall Equipment Effectiveness ( OEE ) adalah perhitungan yang digunakan untuk menentukan tingkat efektivitas peralatan. Nilai Overall Equipment Effectiveness ( OEE ) merupakan perkalian dari nilai Availability (AV), Performance efficiency (PE) dan Rate of quality product $(R Q P)$.

a. Availability (AV)

Merupakan rasio operation time terhadap waktu loading timenya. Sehingga untuk dapat menghitung availability mesin dibutuhkan nilai-nilai dari Waktu Operasi (Operation time), Waktu Persiapan (Loading time), Waktu tidak bekerja (Downtime). Nilai availability dihitung dengan rumus sebagai berikut : 


$$
\text { Availability }=\frac{\text { Loading time-Downtime }}{\text { Loading time }} \times 100 \%
$$

b. Performance efficiency (PE)

Tiga faktor penting yang dibutuhkan untuk menghitung Performance efficiency Ideal cycle time (waktu siklus ideal/waktu standar) Processed amount (jumlah produk yang diproses) Operation time (waktu operasi mesin). Performancy effieciency dapat dihitung sebagai berikut :

Performance ef ficiency $=\frac{\text { Processed amount } x \text { ideal cycle time }}{\text { Operating time }} \times 100 \%$

c. Rate of quality product (RQP)

Adalah rasio jumlah produk yang baik terhadap jumlah total produk yang diproses. Jadi Rate of quality products adalah hasil perhitungan dengan menggunakan dua faktor yaitu Processed amount (jumlah produk yang diproses) Defect amount (jumlah produk yang cacat) of quality products dapat dihitung sebagai berikut :

Rate of Quality Product $=\frac{\text { Processed Amount-Defect Amount }}{\text { Processed Amount }} \times 100 \%$

2. Menghitung six big losses

Untuk dapat meningkatkan produktifitas mesin/peralatan yang digunakan maka perlu dilakukan analisis produktivitas dan efesiensi mesin/peralatan pada six big losses, Adapun ke enam kerugian besar (six big losses) tersebut adalah sebagai berikut:

a. Equipment failure/breakdowns (Kerugian karena kerusakan peralatan).

Untuk mencari besarnya persentase efektivitas mesin yang hilang akibat dari faktor breakdown losses dapat dihitung dengan menggunakan rumus sebagai berikut :

Equipment failure/breakdowns $=\frac{\text { Total Breakdown Time }}{\text { loading time }} \times 100 \%$

b. Set-up and Ajusstment (kerugian karena pemasangan dan penyetelan)

Untuk mengetahui besar persentase setup and Adjustment loss oleh waktu setup Mesin tersebut dapat ditentukan dengan menggunakan rumus sebagai berikut:

$$
\text { Set-up and Ajusstment }=\frac{\text { total setup /adjustment }}{\text { loading time }} \times 100 \%
$$

c. Idling and minor stoppages (Kerugian kerena beroperasi tanpa beban maupun berhenti sesaat)

Untuk dapat mengetahui besarnya faktor efektivitas yang hilang akibat dari terjadinya Idling and Minor Stoppages digunakan rumus sebagai berikut :

$$
\text { Idling and minor stoppages }=\frac{\text { Non Productive Time }}{\text { Loading Time }} \times 100 \%
$$

d. Reduced speed (Kerugian karena kecepatan Produksi)

Untuk mengetahui besarnya persentase Reduce Speed Losses, maka digunakan rumus sebagai berikut :

Reduced speed $=\frac{\text { operation time }-(\text { Ideal Cycle Time } x \text { Result } \text { Processed })}{\text { Loading } \text { Time }} \times 100 \%$

e. Proses defect (Kerugian karena produk cacat maupun karena kerja produk di proses ulang)

Untuk mengetahui besarnya persentase Defect Loss, maka digunakan rumus sebagai berikut :

$$
\text { Rework }=\frac{\text { Ideal Cycle time } x \text { Rework }}{\text { Loading time }} \times 100 \%
$$


f. Reduced yield losses (Kerugian pada awal waktu produksi hingga mencapai waktu produksi yang stabil)

Untuk mengetahui besarnya persentase yield loss, maka digunakan rumus sebagai berikut :

$$
\text { Yield/Scrap loss }=\frac{\text { Ideal cycle } x \text { Scrap }}{\text { Loading time }} \times 100 \%
$$

\section{Failure Mode and Effect Analysis ( FMEA)}

Merupakan metode untuk mengidentifikasi kemungkinan penyebab kegagalan sehingga dengan begitu penyebab dapat dihilangkan. Penilaian pada masing- masing potensi yang didasarkan pada tingkat keparahan (Severity), tingkat kejadian (occurrence) dan kemungkinan terdeteksi (Detection). Dari ketiga ukuran ini bisa didapatkan nilai RPN (Risk Priority Number) menggunakan rumus:

$$
\text { Risk Priority Number }=\text { Severity } x \text { Occurrence } x \text { Detection }
$$

\section{HASIL DAN PEMBAHASAN}

\section{Perhitungan Nilai Availability}

Berdasarkan data Periode Juni 2017- Mei 2018 yang telah didapat dan dilakukan pengolahan menggunakan persamaan 1 nilai Availability pada mesin Open Top Roller dapat dilihat pada tabel 2 .

Tabel 2. Nilai Avaibility Mesin Open Top Roller Periode 2017-2018

\begin{tabular}{|c|c|c|c|c|c|}
\hline \multirow{4}{*}{ Tahun } & $\begin{array}{c}\text { Periode } \\
\text { (Bulan) }\end{array}$ & $\begin{array}{c}\text { loading } \\
\text { time }( \\
\text { jam })\end{array}$ & $\begin{array}{c}\text { Unplanned } \\
\text { Downtime } \\
(\text { jam })\end{array}$ & $\begin{array}{c}\text { operation } \\
\text { time } \\
(\mathrm{jam})\end{array}$ & $\begin{array}{c}\text { Availability } \\
(\%)\end{array}$ \\
\hline \multirow{4}{*}{2017} & Juni & 409 & 57.25 & 351.75 & 86.00 \\
\cline { 2 - 6 } & July & 493 & 38.25 & 454.75 & 92.24 \\
\cline { 2 - 6 } & Agustus & 514 & 52.50 & 461.50 & 89.79 \\
\cline { 2 - 6 } & September & 472 & 52.30 & 419.70 & 88.92 \\
\cline { 2 - 6 } & Oktober & 514 & 38.50 & 475.50 & 92.51 \\
\cline { 2 - 6 } & November & 514 & 38.50 & 475.50 & 92.51 \\
\cline { 2 - 6 } & Desember & 472 & 64.30 & 407.70 & 86.38 \\
\hline \multirow{4}{*}{2018} & Januari & 514 & 38.50 & 475.50 & 92.51 \\
\cline { 2 - 6 } & Februari & 451 & 47.75 & 403.25 & 89.41 \\
\cline { 2 - 6 } & Maret & 493 & 51.80 & 441.20 & 89.49 \\
\cline { 2 - 6 } & April & 451 & 47.75 & 403.25 & 89.41 \\
\cline { 2 - 6 } & Mei & 472 & 58.00 & 414.00 & 87.71 \\
\hline
\end{tabular}

Pada tabel 2 tampak bahwa nilai Availability mesin Open Top Roller dalanm setahun dibilang cukup baik dikarenakan rata-rata angka diatas hanya sebesar $89.74 \%$ namun belum memenuhi standart world class menurut Nakajima dimana nilai Availability yaitu $\geq 90.0 \%$

Presentase Availability pada mesin Open Top Roller lebih jelas diperlihatkan bentuk grafik seperti dibawah pada gambar 2 . 


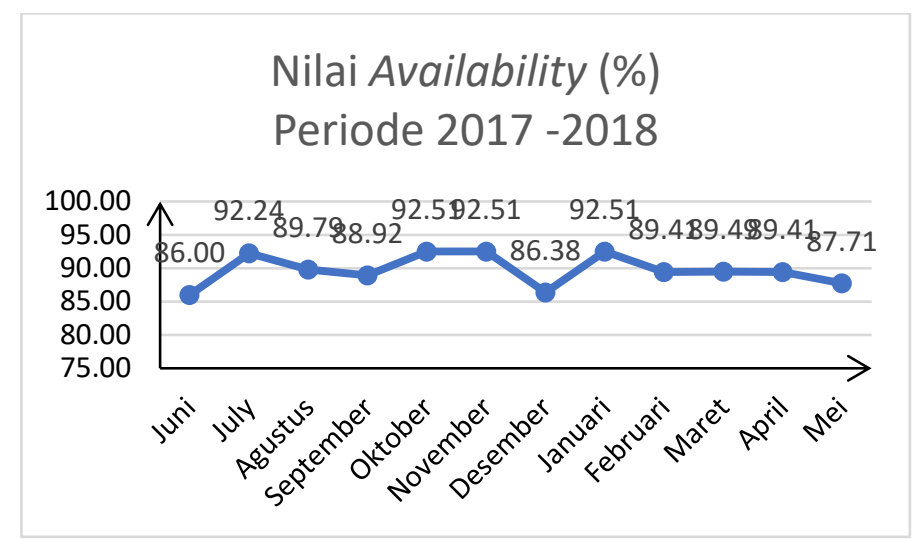

Gambar 2. Grafik Nilai Availability Mesin Open Top Roller

Dari grafik diatas Diketahui Nilai Availability yang paling rendah berada pada bulan Juni yaitu $86.00 \%$ dan yang paling tinggi pada bulan Oktober, November dan Januari diangka $92,51 \%$.

Tinggi rendahnya nilai Availability pada Mesin Open Top Roller Dipengaruhi oleh Loding Time, UnPlanned Downtime, dan Operation Time, sebagai contoh dapat dilihat pada bulan Januari dengan nilai Availability tertinggi yaitu sebesar $92.51 \%$

2. Perhitungan nilai Performance efficiency

Berdasarkan data Periode Juni 2017- Mei 2018 yang telah didapat dan dilakukan pengolahan menggunakan persamaan 2 nilai Performance efficiency pada mesin Open Top Roller dapat dilihat pada tabel 3.

Tabel 3. Performance Efficiency periode Juni 2017 - Mei 2018

\begin{tabular}{|c|c|c|c|c|c|}
\hline \multirow{4}{*}{ Tahun } & $\begin{array}{c}\text { Periode } \\
\text { (Bulan) }\end{array}$ & $\begin{array}{c}\text { Ideal } \\
\text { Cycle } \\
\text { Time (Jam } \\
/ \text { /Kg) }\end{array}$ & $\begin{array}{c}\text { Operation } \\
\text { Time (Jam) }\end{array}$ & $\begin{array}{c}\text { Gross } \\
\text { Product } \\
\text { (kg) }\end{array}$ & $\begin{array}{c}\text { Performance } \\
\text { Efficieency (\%) }\end{array}$ \\
\hline \multirow{7}{*}{2017} & Juni & 0.002 & 351.75 & 142308 & 80.91 \\
\cline { 2 - 6 } & July & 0.002 & 454.75 & 163688 & 71.99 \\
\cline { 2 - 6 } & Agustus & 0.002 & 461.50 & 164427 & 71.26 \\
\cline { 2 - 6 } & September & 0.002 & 419.70 & 160980 & 76.71 \\
\cline { 2 - 6 } & Oktober & 0.002 & 475.50 & 188900 & 79.45 \\
\cline { 2 - 6 } & November & 0.002 & 475.50 & 174614 & 73.44 \\
\cline { 2 - 6 } & Desember & 0.002 & 407.70 & 160224 & 78.60 \\
\hline \multirow{4}{*}{2018} & Januari & 0.002 & 475.50 & 185058 & 77.84 \\
\cline { 2 - 6 } & Februari & 0.002 & 403.25 & 157003 & 77.87 \\
\cline { 2 - 6 } & Maret & 0.002 & 441.20 & 161490 & 73.21 \\
\cline { 2 - 6 } & April & 0.002 & 403.25 & 142538 & 70.69 \\
\cline { 2 - 6 } & Mei & 0.002 & 414.00 & 160493 & 77.53 \\
\hline
\end{tabular}

Berdasarkan tabel diatas diketahui bahwa nilai paling rendah pada Performance efficiency mesin Open Top Roller berada pada bulan April 2018 hanya mencapai 70.60\% sedangkan nilai tertinggi berada bulan Juni 2017 sebesar 80.91\%. 
Berikut ini adalah merupakan perbandingan persentase Performance Efficiency dari mesin Open Top Roller dalam bentuk grafik.

\section{Performance Effeciency (\%) Periode 2017-2018}

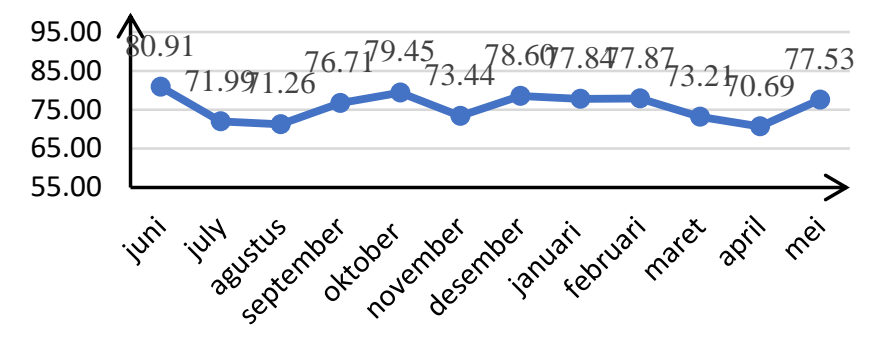

Gambar 3. Diagram Performance Efficiency

Berdasarkan gambar 3 diatas diketahui penyebab rendahnya nilai Performance efficiency mesin Open Top Roller disebabkan oleh perbandingan jumlah produksi dan operation time yang relative tinggi yaitu pada bulan April 2018 dengan nilai 70.69\% dan sebaliknya tingginya nilai Performance efficiency mesin Open Top Roller disebabkan perbandingan produksi dan operation time yang relative rendah dapat dilihat pada bulan juni dengan nilai $80.91 \%$

Tinggi rendahnya nilai Performance efficiency mesin Open Top Roller diebabkan antara operation time dengan ideal cycle time yang sangat jauh. Operation time tidak dapat mendekati ideal cycle time pada setiap bulannya, hal ini disebabkan oleh idling and minor stoppages losses dan reduced speed losses.

\section{Perhitungan nilai Rate of quality product}

Berdasarkan data Periode Juni 2017- Mei 2018 yang telah didapat dan dilakukan pengolahan menggunakan persamaan 3 nilai Rate of quality product pada mesin Open Top Roller dapat dilihat pada tabel 4.

Tabel 4 Rate of quality product periode Juni 2017 - Mei 2018

\begin{tabular}{|c|c|c|c|c|}
\hline \multirow{3}{*}{ Tahun } & $\begin{array}{c}\text { Periode } \\
(\text { Bulan })\end{array}$ & $\begin{array}{c}\text { Defect } \\
\text { Emount } \\
(\mathrm{kg})\end{array}$ & $\begin{array}{c}\text { Gross } \\
\text { Product } \\
(\mathrm{kg})\end{array}$ & $\begin{array}{c}\text { Rate Of } \\
\text { Quality } \\
\text { Product (\%) }\end{array}$ \\
\hline \multirow{4}{*}{2017} & Juni & 0 & 142308 & 100 \\
\cline { 2 - 5 } & July & 0 & 163688 & 100 \\
\cline { 2 - 5 } & Agustus & 0 & 164427 & 100 \\
\cline { 2 - 5 } & September & 0 & 160980 & 100 \\
\cline { 2 - 5 } & Oktober & 0 & 188900 & 100 \\
\cline { 2 - 5 } & November & 0 & 174614 & 100 \\
\cline { 2 - 5 } & Desember & 0 & 160224 & 100 \\
\hline \multirow{4}{*}{2018} & Januari & 0 & 185058 & 100 \\
\cline { 2 - 5 } & Februari & 0 & 157003 & 100 \\
\cline { 2 - 5 } & Maret & 0 & 161490 & 100 \\
\cline { 2 - 5 } & April & 0 & 142538 & 100 \\
\cline { 2 - 5 } & Mei & 0 & 160493 & 100 \\
\hline
\end{tabular}


Dikarenakan pada mesin Open top Roller ini tidak memiliki produk sisa atau cacat maka Persentase Rate Of Quality Product adalah 100\%. Maka yang terlihat dari pengolahan data diatas mencapai angka World class Of OEE untuk Rate Of Quality Product 99\%

4. Perhitungan nilai Overall Equipment Effectivenes (OEE)

Setelah nilai availability, performance efficiency dan rate of quality product pada Mesin Open Top Roller diperoleh maka dilakukan perhitungan nilai Overall Equipment Effectivenes $(O E E)$ untuk mengetahui besarnya efektivitas penggunaan Mesin Open Top Roller. Nilai Overall Equipment Effectivenes (OEE) dapat dilihat pada tabel 5.

Tabel 5. Nilai Overall Equipment Effectivenes mesin Open Top Roller periode Juni 2017 Mei 2018

\begin{tabular}{|c|c|c|c|c|c|}
\hline \multirow{4}{*}{ Tahun } & Bulan & $\begin{array}{c}\text { Availability } \\
(\%)\end{array}$ & $\begin{array}{c}\text { Performance } \\
\text { Effciency } \\
(\%)\end{array}$ & $\begin{array}{c}\text { Rate Of } \\
\text { Quality } \\
\text { Product } \\
(\%)\end{array}$ & $\begin{array}{c}\text { Overall } \\
\text { Equipment } \\
\text { Effectivenes } \\
(\%)\end{array}$ \\
\hline \multirow{7}{*}{2017} & Juni & 86.00 & 80.91 & 100 & 69.59 \\
\cline { 2 - 6 } & July & 92.24 & 71.99 & 100 & 66.40 \\
\cline { 2 - 6 } & Agustus & 89.79 & 71.26 & 100 & 63.98 \\
\cline { 2 - 6 } & September & 88.92 & 76.71 & 100 & 68.21 \\
\cline { 2 - 6 } & Oktober & 92.51 & 79.45 & 100 & 73.50 \\
\cline { 2 - 6 } & November & 92.51 & 73.44 & 100 & 67.94 \\
\cline { 2 - 6 } & Desember & 86.38 & 78.60 & 100 & 67.89 \\
\hline \multirow{4}{*}{2018} & Januari & 92.51 & 77.84 & 100 & 72.01 \\
\cline { 2 - 6 } & Februari & 89.41 & 77.87 & 100 & 69.62 \\
\cline { 2 - 6 } & Maret & 89.49 & 73.21 & 100 & 65.51 \\
\cline { 2 - 6 } & April & 89.41 & 70.69 & 100 & 63.21 \\
\cline { 2 - 6 } & Mei & 87.71 & 77.53 & 100 & 68.01 \\
\hline
\end{tabular}

Dari Hasil pengolahan data diatas dapat dilihat nilai OEE tertinggi terdapat pada bulan Oktober 2017 yaitu sebesar 73.50\% dan terendah pada bulan April 2018 yaitu sebesar 63,21\%.

Perbandingan persentase Overall Equipment Effectiveness (OEE) diperlihatkan dalam bentuk grafik dapat dilihat pada gambar 4 .

\section{Overall Equipment Effectiveness Periode $2017-2018$}

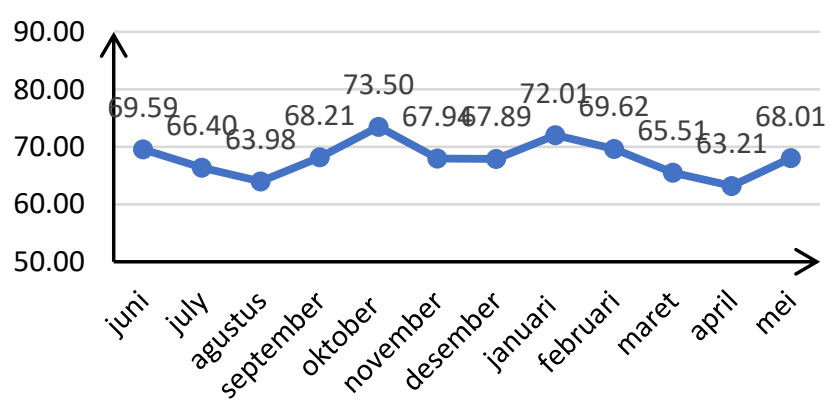

Gambar 4. Grafik Overall Equioment Effectiveness 
Secara keseluruhan nilai OEE yang dicapai mesin Open Top Roller di pabrik PT. Perkebunan IV Unit Bah Butong belum Memenuhi World Class Of OEE 85\% hal ini disebabkan karena rendahnya beberapa faktor yang mempengaruhi nilai OEE itu sendiri seperti Perfomance Efficiency, Availibility

\section{Perhitungan Six big losses}

Six big losses adalah faktor-faktor yang menyebabkan keefektifan mesin Open Top Roller menurun dari keadaan standarnya pada saat mesin sedang beroperasi, adapun keenam factor tersebut adalah breakdown, setup and adjustment, idling and minor stoppages, reduced speed, rework loss, dan yield/scraft loss. Adapun hasil perhitungan Six big losses pada tabel 6 berikut:

Tabel 6. Persentase faktor Six Big Losses mesin Open Top Roller Periode Juni 2017-Mei 2018.

\begin{tabular}{|c|c|c|c|}
\hline No & Six Big Losses & $\begin{array}{c}\text { Total Time Loss } \\
(\text { jam })\end{array}$ & $\begin{array}{c}\text { Persentase } \\
(\%)\end{array}$ \\
\hline 1 & Break down losses & 512.15 & 25.94 \\
\hline 2 & Setup and adjusment & 73.25 & 3.71 \\
\hline 3 & Idling and minor stoppages & 128.75 & 6.52 \\
\hline 4 & Reduced speed losses & 1260.15 & 63.83 \\
\hline 5 & Scrap/yield loss & 0.00 & 0.00 \\
\hline 6 & Rework losses & 0.00 & 0.00 \\
\hline Total & & 1974.3 & 100 \\
\hline
\end{tabular}

Dari tabel 6 dapat dilihat bahwa factor yang memiliki persentase terbesar dari keenam factor tersebut adalah reduced speed losses sebesar $63.83 \%$.

6. Penyusunan Failure Mode and Effet Analsis (FMEA)

Melalui FMEA didapatkan hasil penilaian Risk Priority Number (RPN) komponen mesin Open Top Roller untuk Silinder penggulung, Meja penggiling, Poros engkol, V-belt, , dan electro motor. Sebelum membuat tabel FMEA terlebih dahulu harus memiliki data historis sebagai acuan untuk mengarahkan untuk mengetahui dasar dari kerusakan, akibatnya terhadap sistem, dan dampaknya terhadap keseluruhan sistem. Dampak kegagalan dari komponen mesin Open Top Roller. Berikut tabel Failure Mode and Effet Analsis (FMEA) mesin Open Top Roller pada tabel 7.

Tabel 7. Failure Mode and Effet Analsis (FMEA) mesin Open Top Roller 


\begin{tabular}{|c|c|c|c|c|c|c|c|c|c|c|}
\hline No & Komponen & Failure mode & Failure Cause & Failure effect & $\mathbf{S}$ & $\mathbf{O}$ & D & RPN & $\begin{array}{l}\mathbf{R} \\
\mathbf{a} \\
\mathbf{n} \\
\mathbf{k}\end{array}$ & Rekomendasi \\
\hline 1 & $\begin{array}{l}\text { Silinder } \\
\text { Penggulung }\end{array}$ & $\begin{array}{l}\text { Pelat Silinder } \\
\text { penggulung } \\
\text { rusak, dan } \\
\text { sambungan } \\
\text { Pelat putus }\end{array}$ & $\begin{array}{l}\text { Akibat } \\
\text { Pembebanan } \\
\text { yang secara } \\
\text { terus menerus }\end{array}$ & $\begin{array}{l}\text { Silinder Penggulung } \\
\text { tidak bekerja efektif }\end{array}$ & 7 & 3 & 1 & 21 & 5 & Preventive maintenance \\
\hline 2 & $\begin{array}{l}\text { Meja } \\
\text { Penggiling }\end{array}$ & $\begin{array}{l}\text { Meja } \\
\text { penggiling } \\
\text { rusak }\end{array}$ & $\begin{array}{l}\text { Aus pada Cones } \\
\text { dan Batten }\end{array}$ & $\begin{array}{l}\text { Proses penggilingan } \\
\text { tidak sempurna }\end{array}$ & 7 & 3 & 5 & 105 & 2 & Corrective maintenance \\
\hline 3 & \begin{tabular}{|l|} 
Poros \\
Engkol
\end{tabular} & $\begin{array}{l}\text { Poros engkol } \\
\text { rusak }\end{array}$ & $\begin{array}{l}\text { Shaft unbalance } \\
\text { yang } \\
\text { diakibatkan } \\
\text { bearing pecah }\end{array}$ & $\begin{array}{l}\text { Putaran yang } \\
\text { didistribusikan } \\
\text { electromotor tidak } \\
\text { optimal }\end{array}$ & 8 & 3 & 5 & 120 & 1 & Preventive maintenance \\
\hline 4 & $\begin{array}{l}\text { Eletro } \\
\text { Motor }\end{array}$ & $\begin{array}{l}\text { Electro motor } \\
\text { rusak }\end{array}$ & $\begin{array}{l}\text { Cooling Fan } \\
\text { patah, kumparan } \\
\text { rusak }\end{array}$ & $\begin{array}{l}\text { Proses produksi tidak } \\
\text { dapat beroperasi }\end{array}$ & 7 & 3 & 3 & 63 & 3 & Preventive maintenance \\
\hline 5 & $V$-Belt & $\begin{array}{l}V \text {-belt longgar } \\
\text { dan putus }\end{array}$ & $\begin{array}{l}\text { Thermal Stress } \\
\text { akibat putaran }\end{array}$ & $\begin{array}{l}\text { Putaran Open Top } \\
\text { Roller lebih lambat } \\
\text { dan terhenti }\end{array}$ & 5 & 3 & 2 & 30 & 4 & Corrective maintenance \\
\hline
\end{tabular}

\section{KESIMPULAN}

Berdasarkan analisis hasil dari pengukuran Overall Equipment Effectiveness (OEE) pada mesin Open Top Roller di PT. Perkebunan Nusantara IV Unit Bah Butong dapat diambil beberapa kesimpulan sebagai berikut :

1. Nilai OEE terendah di periode April 2018 yaitu sebesar 63,21\% dan nilai tertinggi pada periode Oktober 2017 yaitu sebesar 73.50\%. Dan Faktor yang mempengaruhi tingkat efektivitas mesin Open Top Roller adalah

- Availability dengan nilai rata-rata sebesar $89.74 \%$ pada periode Juni 2017 - Mei 2018,

- performance Efficiency dengan nilai rata-rata sebesar $75.79 \%$ pada periode Juni 2017 - Mei 2018.

- Rate of Quality Porduct (RQP) dengan persentase $100 \%$ dikarenakan tidak adanya produk gagal.

2. Akar penyebab dari permasalahan pada Six Big Losses mesin Open Top Roller terdapat pada faktor Break down losses sebesar 25.94\% dan Reduce Speed Losses sebesar 63.83\%.

3. Melalui Analisa Failure Mode and Effect Analysis (FMEA) diketahui bahwa komponen mesin Open Top Roller yang paling dominan menyebabkan kerukakan adalah nilai Risk Priority Number (RPN) lebih tinggi, yaitu pada Poros engkol sebesar $=120$

\section{REFERENSI}

Ahyari, Agus. 2002, Manajemen Produksi dan Pengendalian Produksi, Yogyakarta, BPFE.

Assauri, Sofjan. 1999. Manajemen Produksi dan Operasi. Salemba Empat, Jakarta.

Assauri, Sofjan. 2008. Manajemen Produksi dan Operasi. Lembaga Penerbit Fakultas Ekonomi

Universitas Indonesia. Jakarta.

Corder, antony dan Kusnul Hadi. 1992 “Teknik manajemen pemeliharaan” Jakarta: Erlangga

Dyadem Engineering Corporation. 2003. Guidelines for Failure Mode and Effects Analysis, For

Automotive, Aerospace and General Manufacturing Industries. Kanada: CRC Press.

http://andipranan87.blogspot.com/2014/09/teori-sistem-pemeliharaan-aset.html (diakses pada 10 november 2018)

http://indroagunghandoko.blogspot.com/p/additional-3.html (diakses pada 10 november 2018) http://www.plant-maintenance.com/articles/RCMvTPM.shtml (diakses pada 10 november 2018) 
https://www.oee.com/world-class-oee.html (diakses pada 10 november 2018)

Ljungberg, O. (1998). Measurement of Overall Equipment Effectiveness As a Basis for TPM Activities. International Journal of Operations \& Production Management.

Nakajima, S. 1988. Introduction to Total Productive Maintenance. Cambridge: MA,Productive Press, Inc.

Nasution, Arman. H, 2006, Manajemen Industri. Yogyakarta: Andi Offset.

Tampubolon, P. Manahan, 2004, Manajemen Operasional, edisi pertama, Ghalia Indonesia

Tindaon. R.F. 2009. Identifikasi Sistem Proses produksi Teh Di PT. Perkebunan Nusantara IV Kebun Bah Butong. Departemen Teknologi Pertanian. Fakultas Pertanian. Universitas Sumatera Utara. Medan. 